\title{
Vitamin D intakes and dietary sources in children aged 2 yrs in the Cork BASELINE Birth Cohort Study
}

\author{
C. ní Chaoimh ${ }^{1}$, E. K. McCarthy ${ }^{1}$, D. M. Murray ${ }^{2}$, L. C. Kenny ${ }^{3}$, J. O’B. Hourihane ${ }^{2}$, A. D. Irvine ${ }^{4,5}$, \\ J. Lyons ${ }^{1}$ and M. Kiely ${ }^{1}$ \\ ${ }^{1}$ Vitamin D Research Group, School of Food and Nutritional Science, ${ }^{2}$ Department of Paediatrics and Child Health, ${ }^{3}$ Anu \\ Research Centre, Department of Obstetrics and Gynaecology, University College Cork, ${ }^{4}$ Department of Clinical Medicine, \\ Trinity College, ${ }^{5}$ Department of Paediatric Dermatology, Our Lady's Children's Hospital, Dublin, Ireland
}

The US Institutes of Medicine estimated average requirement (EAR) for vitamin D is $10 \mu \mathrm{g} / \mathrm{d}$ (400 IU/d) for children above one year ${ }^{(1)}$. We have reported vitamin D intakes in Irish children (aged 5-12 yrs) and adolescents (aged 13-17 yrs) that are substantially below the $\mathrm{EAR}^{(2)}$. The current analysis aimed to estimate intakes, prevalence of inadequate intakes, and dietary sources of vitamin $\mathrm{D}$ in younger children in Ireland.

Food consumption data for this analysis was collected in the form of a two-day weighed food diary from participants of the Cork BASELINE Birth Cohort Study at their 24-month follow-up. One hundred and thirty seven food diaries were collected and analysed using updated food consumption data for vitamin D from international sources to reflect currently available analytical data ${ }^{(2)}$. Values for nutritional supplements and brand-level foods were updated based on current market data and from the Irish Food Composition Database $^{(3)}$.

The mean daily intake (MDI) of vitamin D from all sources in the total study population was $3.8 \mu \mathrm{g}$ and almost everyone (94\%) had intakes below the EAR of $10 \mu \mathrm{g} / \mathrm{d}$. 'Growing-up milk' was an important source of vitamin D among 2-year olds, and contributed $61 \%$ to total intakes of $7.6 \mu \mathrm{g} / \mathrm{d}$ among consumers. Fortified milk and yogurts, nutritional supplements and breakfast cereals were important sources of vitamin D, see table. Intakes from the base diet were low; with actual contributions from meat, fish, eggs, and non-fortified milk and yogurts ranging from 0.1 to $0.4 \mu \mathrm{g} / \mathrm{d}$, regardless of supplement use or fortified food consumption. The prevalence of vitamin Dcontaining supplement use was $<10 \%$ and the mean intake of vitamin D in supplement users was $9.2 \mu \mathrm{g} / \mathrm{d}$; $67 \%$ had intakes below the EAR. Non-users of vitamin D-containing supplements who consumed vitamin D fortified foods had an intake of $3.9 \mu \mathrm{g}$ compared with $1.2 \mu \mathrm{g}$ in those who did not use supplements and did not consume fortified foods.

\begin{tabular}{|c|c|c|c|c|c|c|c|c|c|c|}
\hline \multirow[b]{2}{*}{ Food Group } & \multicolumn{2}{|c|}{$\begin{array}{c}\text { Total population } \\
(n=137)\end{array}$} & \multicolumn{2}{|c|}{$\begin{array}{l}\text { Supplement users, fortified } \\
\text { food consumers }(n=107)\end{array}$} & \multicolumn{2}{|c|}{$\begin{array}{l}\text { Growing-up milk } \\
\text { consumers }(n=31)\end{array}$} & \multicolumn{2}{|c|}{$\begin{array}{c}\text { Supplement users } \\
(n=12)\end{array}$} & \multicolumn{2}{|c|}{$\begin{array}{l}\text { Non users of supplements } \\
\text { or fortified foods }(n=30)\end{array}$} \\
\hline & $\%$ & $\mu \mathrm{g} \backslash \mathrm{d}$ & $\%$ & $\mu \mathrm{gld}$ & $\%$ & $\mu \mathrm{gld}$ & $\%$ & $\mu \mathrm{gld}$ & $\%$ & $\mu \mathrm{gld}$ \\
\hline Growing-Up Milk & 28 & 1.0 & 30 & 1.3 & 61 & 4.6 & 17 & 1.6 & 0 & 0.0 \\
\hline Vitamin D fortified milk and yogurts & 19 & 0.7 & 20 & 0.9 & 6 & 0.5 & 19 & 1.7 & 0 & 0.0 \\
\hline Breakfast cereals & 10 & 0.4 & 10 & 0.5 & 6 & 0.5 & 9 & 0.8 & 6 & 0.1 \\
\hline Nutritional Supplements & 9 & 0.4 & 10 & 0.5 & 11 & 0.8 & 45 & 4.1 & 0 & 0.0 \\
\hline Non-fortified milk and yogurts & 9 & 0.3 & 7 & 0.3 & 3 & 0.2 & 1 & 0.1 & 30 & 0.4 \\
\hline Fish and fish dishes & 6 & 0.2 & 5 & 0.2 & 3 & 0.2 & 3 & 0.3 & 7 & 0.1 \\
\hline Meat and meat products & 8 & 0.3 & 6 & 0.3 & 3 & 0.2 & 3 & 0.2 & 23 & 0.3 \\
\hline Eggs and egg dishes & 4 & 0.2 & 3 & 0.1 & 2 & 0.2 & 1 & 0.0 & 23 & 0.3 \\
\hline Butter and fat spread & 3 & 0.1 & 3 & 0.1 & 2 & 0.2 & 1 & 0.1 & 3 & 0.03 \\
\hline Other & 4 & 0.2 & 4 & 0.2 & 3 & 0.2 & 1 & 0.1 & 7 & 0.1 \\
\hline Mean daily intake vitamin D (ug/d) & \multicolumn{2}{|c|}{3.8} & \multicolumn{2}{|c|}{4.5} & \multicolumn{2}{|c|}{7.6} & \multicolumn{2}{|c|}{9.2} & \multicolumn{2}{|c|}{1.2} \\
\hline
\end{tabular}

Results show that despite consumption of fortified foods among $78 \%$ of the study population, the current supply of vitamin D in the diets of toddlers living in Ireland is unable to deliver vitamin D at the recommended levels. The impact of these relatively low intakes of vitamin D on serum 25-hydroxyvitamin D levels in this population is currently under investigation.

The Cork BASELINE birth cohort study is supported by the National Children's Research Centre.

1. Institute of Medicine (2011) National Academies Press.

2. Black LJ, Walton J, Flynn A, Kiely M. (2013) Public Health Nutr 27, 1-11.

3. Black LJ, Ireland J, Møller A, Roe M, Walton J, Flynn A, Finglas PM \& Kiely M (2011) J Food Comp Anal 24, $1017-1023$. 